\title{
Soil chemical factors and grassland species density in Emas National Park (central Brazil)
}

\author{
Amorim, PK.* and Batalha, MA. \\ Departamento de Botânica, Universidade Federal de São Carlos - UFSCar, \\ CP 676, CEP 13565-905, São Carlos, SP, Brazil \\ *e-mail: prikobarim@yahoo.com.br
}

Received June 8, 2006 - Accepted October 2, 2006 - Distributed May 31, 2008

(With 1 figure)

\begin{abstract}
Studies of grasslands on specific soil types suggest that different nutrients can limit biomass production and, hence, species composition and number. The Brazilian cerrado is the major savanna region in America and once covered about 2 million $\mathrm{km}^{2}$, mainly in the Brazilian Central Plateau, under seasonal climate, with wet summer and dry winter. In view of the importance of soil chemical factors in the distribution of the vegetation forms within the Cerrado domain and which may influence the number of species, we analyzed some soil characteristics in three herbaceous vegetation forms - hyperseasonal cerrado, seasonal cerrado, and wet grassland - in Emas National Park, a core cerrado site, to investigate the relationship between number of species and soil characteristics. We collected vegetation and soil samples in these three vegetation forms and submitted the obtained data to multiple linear regression. We found out that aluminum and $\mathrm{pH}$ were the best predictors of species density, the former positively related to species density and the latter negatively related. Since the predictable variation in species density is important in determining areas of conservation, we can postulate that these two soil factors are indicators of high species density areas in tropical grasslands, which could be used in selecting priority sites for conservation.
\end{abstract}

Keywords: aluminum, nutrient limitation, $\mathrm{pH}$, soil, species density.

\section{Características químicas do solo e densidade de espécies em comunidades herbáceas no Parque Nacional das Emas (Brasil central)}

\begin{abstract}
Resumo
Estudos em comunidades herbáceas em tipos específicos de solos sugerem que diferentes nutrientes podem limitar a produção de biomassa e, também, a composição e o número de espécies. O cerrado brasileiro é a maior região de savana na América e ocupava, originalmente, cerca de 2 milhões de $\mathrm{km}^{2}$, principalmente no Planalto Central Brasileiro. Encontra-se sob clima estacional, com verão chuvoso e inverno seco. Como as variáveis químicas do solo são importantes na distribuição das formas de vegetação no domínio do Cerrado e podem influenciar no número de espécies, analisamos algumas variáveis edáficas em três formas vegetacionais herbáceas - cerrado hiperestacional, cerrado estacional e campo úmido - no Parque Nacional das Emas, uma região nuclear de cerrado, para investigar quais seriam as relações entre o número de espécies e as características do solo. Coletamos amostras de solo e vegetação nesses três ambientes e submetemos os dados obtidos a uma análise de regressão múltipla linear. Encontramos que o alumínio e o $\mathrm{pH}$ foram os melhores previsores da densidade de espécies, sendo o primeiro relacionado positivamente com a densidade de espécies, e o último, negativamente. Já que a variação previsível na densidade de espécies é importante para se determinar áreas de conservação, podemos postular que esses dois fatores do solo podem ser indicadores de áreas com alta densidade de espécies em comunidades herbáceas tropicais, que poderiam ser usados para a escolha de locais prioritários para conservação.
\end{abstract}

Palavras-chave: alumínio, densidade de espécies, nutrientes limitantes, $\mathrm{pH}$, solo.

\section{Introduction}

In herbaceous communities, the number of species and, biomass appear to present a humped-back relationship (Al-Mufti et al., 1977; Grime, 1979). Biomass, in turn, depends on the production of the community and thus, on the fertility of the soil (Janssens et al., 1998). Therefore, one may expect a humped-back relationship between the number of species and soil fertility as well (Janssens et al., 1998). In this case, species richness would be higher where nutrients are in short supply and, consequently, plants do not grow tall and compete for light - and where environmental stress is not too excessive (Grime, 1979; Moore and Keddy, 1989). Nutrient 
limitation is, indeed, one of the most important factors affecting the structure of plant communities (Grime et al., 1997).

Individual studies of grasslands on specific soil types suggest that different nutrients can limit biomass production and, hence, species composition and number (Critchley et al., 2002a). Whereas phosphorus influences grassland biodiversity (Janssens et al., 1998; McCrea et al., 2001), the role of potassium is less clear. High potassium levels on former arable land are believed to diminish species diversity (Gilbert and Andersen, 1998), although high potassium additions do not alter the floristic composition of experimental hay plots (Elberse et al., 1983). Similarly, the role of $\mathrm{pH}$ is also unclear: on the one hand, $\mathrm{pH}$ was the variable most highly correlated with species richness and diversity in the Netherlands (Roem and Berendse, 2000), but, on the other hand, in some temperate regions of western and central Europe, it was not correlated with them at all (Janssens et al., 1998).

Savannas are tropical and subtropical formations where the grass layer is continuous, occasionally interrupted by shrubs and trees, and with the main growth patterns are closely associated with alternating wet and dry seasons (Bourlière and Hadley, 1983). Based on this seasonality, Sarmiento (1983) suggested a classification of the savannas from an ecological point of view, dividing them into four major categories: I) semi-seasonal savannas, which occur under a mostly wet climate, with one or two short dry seasons; II) seasonal savannas, characterized by an extended rainless season, in which drought and fire provide a neat rhythmicity in its functioning; III) hyperseasonal savannas, characterized by the alternation of two contrasting stresses during each annual cycle, one induced by drought and fire, the other by waterlogging; and IV) marshy savannas, in which the water excess may last most of the year, whereas a period of acute water shortage either does not exist or is very brief.

The Brazilian cerrado is the largest savanna region in South America, occupying formerly 2 million $\mathrm{km}^{2}$, especially in the Brazilian Central Plateau (Ratter et al., 1997). The cerrado vegetation is not uniform in physiognomy, ranging from grassland to tall woodland (Coutinho, 1990), but with most of its physiognomies within the range defined as tropical savannas. Hyperseasonal cerrado areas normally appear in interfluvial regions with poorly drained soils (Sarmiento, 1983), being very restricted within the Cerrado domain, whose cerrado areas are almost seasonal. Nevertheless, Batalha et al. (2005) found a small area, composed of cerrado species, which is the first occurrence of a hyperseasonal cerrado, in Emas National Park (ENP), central Brazil.

Several explanations for the occurrence of savannas, in general, and of the cerrado, in particular, involve soil either as a primary cause or as an indirect factor (Askew and Montgomery, 1983). Given that soil chemical factors are important in the distribution of the vegetation forms within the Cerrado domain and could influence the number of species, we analyzed some soil characteristics in three herbaceous vegetation forms - hyperseasonal cerrado, seasonal cerrado, and wet grassland - in ENP, a core cerrado site. In ENP, number of species is higher in the wet grassland and lower in the hyperseasonal cerrado (Batalha et al., 2005). But, is this pattern related to soil characteristics? That is, regardless of the vegetation form, is there a relationship between soil factors and the number of species in those herbaceous communities? Which soil factors are important in explaining variation in number of species in those grasslands?

\section{Material and Methods}

Created in 1961, the Emas National Park is located in the Brazilian Central Plateau, in the cerrado core region. Recently, ENP was included by Unesco (2001) in the World Natural Heritage List as one of the sites containing flora, fauna, and key habitats that characterize the cerrado. Regional climate is humid tropical with wet summer and three dry months in the winter, classified as Aw according to Köppen's (1931). The cerrado in ENP comprises almost all physiognomies found in this vegetation type, from campo limpo (a grassland) to cerrado sensu stricto (a woodland). In ENP, open cerrado physiognomies are predominant - campo limpo, campo sujo (a shrub savanna), and campo cerrado (a savanna woodland) - occupying $78.5 \%$ of the total area. Other vegetation types, such as wet grassland, riparian forest, and seasonal forest, also exist within the reserve. There is, in the southwestern part of the reserve, a hyperseasonal cerrado area that occupies about 300 ha, waterlogged from February to April.

We established three 1 ha areas in the southwestern portion of the reserve, one composed of hyperseasonal cerrado (approximately, 18 $8^{\circ} 18^{\prime} 07^{\prime \prime} \mathrm{S}$ and $52^{\circ} 57^{\prime} 56^{\prime \prime} \mathrm{W}$ ), one composed of seasonal cerrado (approximately, $18^{\circ} 17^{\prime} 34^{\prime \prime} \mathrm{S}$ and $52^{\circ} 58^{\prime} 12^{\prime \prime} \mathrm{W}$ ) and one composed of wet grassland (approximately, $18^{\circ} 15^{\prime} 40^{\prime \prime} \mathrm{S}$ and $53^{\circ} 01^{\prime} 08^{\prime} \mathrm{W}$ ). Physiognomically, these three vegetation forms are grasslands. In the hyperseasonal cerrado, there are two contrasting stresses during the year, waterlogging in summer and drought in winter; in the seasonal cerrado, there is drought in winter, but no waterlogging; whereas wet grassland is waterlogged throughout most of the year.

In each vegetation form, we placed randomly ten $1 \mathrm{~m}^{2}$ quadrats, in February 2003, in mid-rainy season, and counted the number of individuals of each vascular plant species. We avoided sampling seedlings, due to their dynamic throughout the year. In the case of caespitose herbs, we considered as an individual the whole tuft. We collected botanical material and identified it to species level by comparison with reference vouchers collected by Batalha and Martins (2002), by using identification key based on vegetative characters (Batalha and Mantovani, 1999), or by comparison with lodged vouchers in the São Paulo Botanical Institute herbarium. When we could not identify the collected vouchers to species level, we classified them as morphospecies. We lodged 
the collected material at the Federal University of São Carlos herbarium.

In each point, we also collected soil samples at four depths $(0-0.05,0.05-0.25,0.4-0.6$, and $0.8-1.0 \mathrm{~m})$ for chemical analyses, which were conducted at the Soil Sciences Laboratory of the University of São Paulo. We analyzed soil factors according to the procedures described by Raij et al. (1987): air dried soil samples were sieved $(2.0 \mathrm{~mm})$ and analyzed for total organic matter (OM) by spectrophotometry after oxidation with sodium dichromate in the presence of sulfuric acid and a subsequent titration with ammonic ferrous sulfate; phosphorus $(\mathrm{P})$ was determined by spectrophotometry after anion exchange resin extraction; exchangeable aluminum $(\mathrm{Al})$ and potassium $(\mathrm{K})$ were extracted with $1 \mathrm{~mol}_{\mathrm{c}} \mathrm{l}^{-1} \mathrm{KCl}$, cation exchange resin, and buffer SMP, respectively; and soil $\mathrm{pH}$ was determined in $\mathrm{CaCl}_{2}(0.01 \mathrm{M})$ solution.

For each quadrat, we counted the number of species, which gave us the species density. Thus, we had a matrix with the number of species and soil chemical factors for each one of the 30 quadrats and for each one of the four depths. To test the relationships between species density and soil chemical factors at each depth, we used linear multiple regressions (Jongman et al., 1995). In these analyses, species density was the response variable and the soil chemical factors $-\mathrm{pH}$, organic matter, phosphorus, aluminum, and potassium - were the explanatory variables. We used analyses of variance to test whether the partial regression coefficients were equal to zero.

\section{Results}

Contrary to the expected, we did not find humpedback relationships for none of the analyzed soil chemical factors (Figure 1 - only data for surface soil are shown).

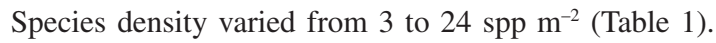
We found significant relationships between the number of species and soil chemical factors for all depths. The depth with the highest coefficient of determination was the superficial one $\left(\mathrm{R}^{2}=0.68, \mathrm{~F}=10.179, \mathrm{P}<0.001\right)$. In this depth, aluminum and $\mathrm{pH}$ were the best predictors of species density, the former positively related to species density and the latter negatively related (Table 2 ).

\section{Discussion}

Humped-back relationships between species density and soil factors may be expected, at least for major soil nutrients, such as phosphorus and potassium (Janssens et al., 1998). Contrary to temperate grasslands (Janssens et al., 1998), the relationship between species density and major soil nutrients may be more complex in tropical grasslands, than in those grasslands within the Cerrado domain. Since we did not find a humped-back relationship between species density and soil factors, we cannot expect a humped-back relationship between species density and biomass in the grasslands we studied as well, contrary to what was found in other herba- ceous communities by Al-Mufti et al. (1977) and Grime (1979).

Differences among species in their abilities to exploit limiting resources affect the coexistence of species (Tilman, 1982). Since some plant species have special adaptations to low nitrogen availability and others to low phosphorus availability, the type of nutrient limitation may affect species composition and richness through its effect on productivity (Venterink et al., 2003). The nutrient mosaic theory states that the mechanism that could help maintain high plant species density involves differentiation in the use of various materials, such as nitrogen, phosphorus, potassium, calcium, and so on; according to this argument, each plant species has its own peculiar set of requirements (Pianka, 1994).

Even if there were significant relationships between species density and soil at all depths, we found a higher correspondence with surface soil, as expected (Amorim and Batalha, 2006; Ruggiero et al., 2002). There is an intimate relationship between the properties of the surface soil horizons and the nature and abundance of plant species, which affects nutrients, as well as water absorption, and retention in the biomass and upper rhizosphere (Furley, 1976). The vegetation itself influences soil characteristics at upper layers, by, for example, transferring organic matter through nutrient cycling (Ruggiero et al., 2002).

In the grasslands we studied, aluminum and $\mathrm{pH}$ were the best predictors of species density, as in The Netherlands (Venterink et al., 2003). In temperate regions, grassland plant species density is generally higher on neutral or basic soils than in acidic soil (Marrs, 1993). For instance, Roem and Berendse (2000) and Critchley et al. (2002b) found a positive relationship between $\mathrm{pH}$ and species density in Europe. Low $\mathrm{pH}$ reduces the mineralization of soil organic matter and other nutrient reserves, inhibiting root growth and, consequently, adsorption of nutrients (Vermeer and Berendse, 1983). In tropical grasslands, such as in Australia, on the other hand, plant species density is negatively correlated with soil pH (Morgan, 1998), corroborating our results. Local relationships between plant species number and soil $\mathrm{pH}$ are related to evolutionary history, thus, the relationship between them should be positive in those floristic regions where the evolutionary center is on high $\mathrm{pH}$ soil - that is, higher latitudes - and negative where the evolutionary center is on low pH soil - that is, lower latitudes (Pärtel, 2002).

Exchangeable aluminum decreases the nutrient availability to the plants by lowering phosphorus absorption or its precipitation in intercellular spaces (Malavolta et al., 1977). Aluminum also causes a decrease in magnesium and calcium absorption (Marschner, 1989) and induces a larger decrease in anion uptake - particularly $\mathrm{NO}^{-3}$ - by plant roots (Calba and Jaillard, 1997). Thus, we could expect a negative relationship between aluminum and species density. However, we found a positive relationship in the grasslands we studied. Braakhekke 

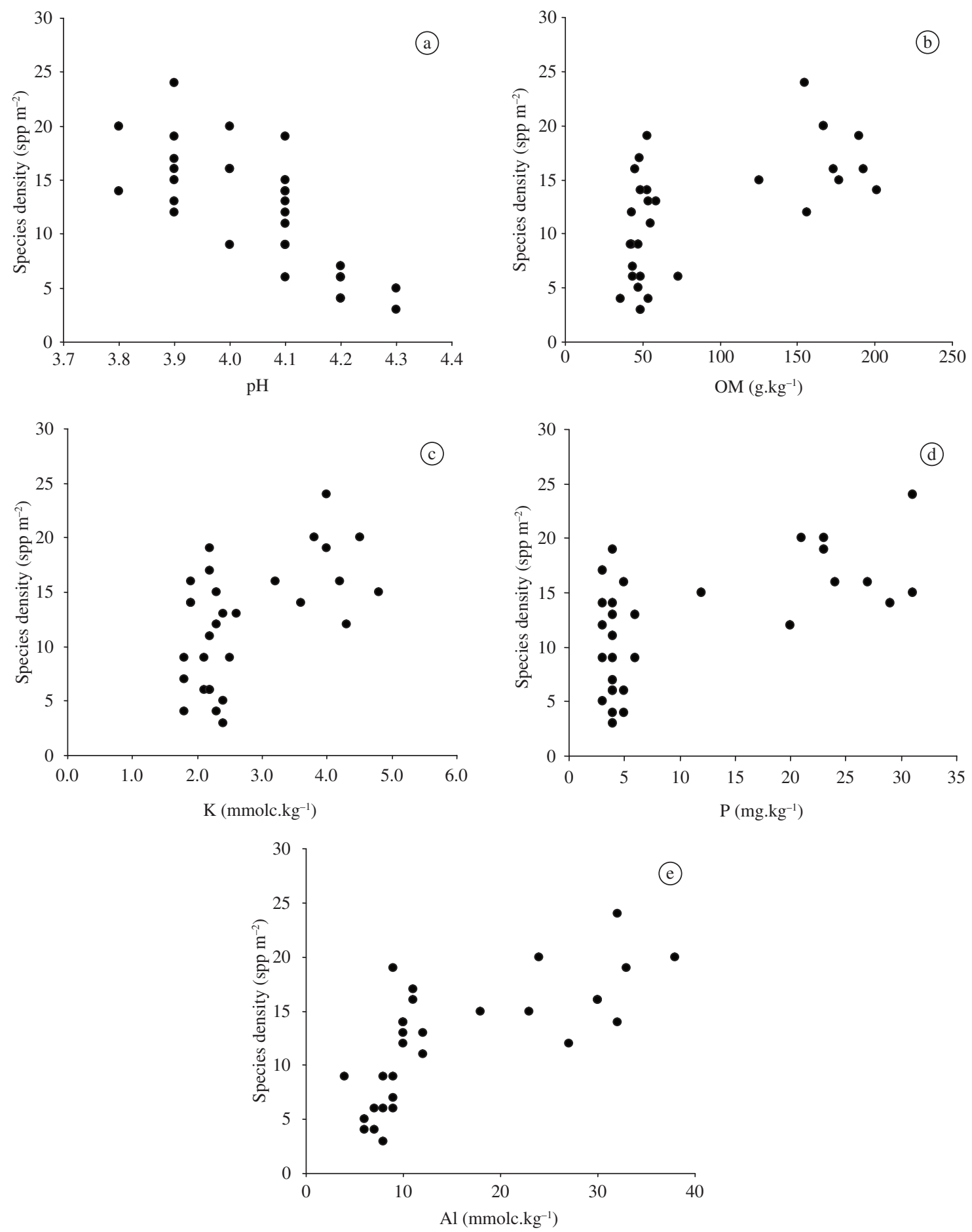

Figure 1. Relationship between a) $\mathrm{pH}$; b) $\mathrm{OM}$; c) K ; d) P; and e) Al, at 0-0.05 m deep, and species density (spp $\left.\mathrm{m}^{-2}\right)$ in grassland communities in Emas National Park, central Brazil (18 $15^{\prime}-18^{\circ} 18^{\prime} \mathrm{S}$ and 52 $\left.57-53^{\circ} 01^{\prime} \mathrm{W}\right)$, February 2003.

(1980) and Tilman (1982) suggested that species number is greater in sites where plant growth is limited by several nutrients. Since aluminum decreases nutrient availability, plant growth would be limited by several nutrients in aluminum-rich soils. Thus, we may postulate that the positive relationship aluminum and species density we found is because the grassland species in ENP are limited by several nutrients. This positive relationship between aluminum and species density does not mean that high concentration of aluminum in soil implies high 
Table 1. Species density and soil chemical factors, at 0-0.5 m deep, in grassland communities in Emas National Park, cen-

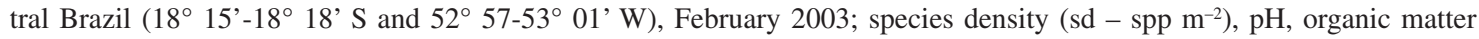
$\left(\mathrm{OM}-\mathrm{g} \cdot \mathrm{kg}^{-1}\right)$, phosphorus $\left(\mathrm{P}-\mathrm{mg} \cdot \mathrm{kg}^{-1}\right)$, aluminum $\left(\mathrm{Al}-\mathrm{mmolc} \cdot \mathrm{kg}^{-1}\right)$, potassium $\left(\mathrm{K}-\mathrm{mmolc} \cdot \mathrm{kg}^{-1}\right)$.

\begin{tabular}{|c|c|c|c|c|c|c|c|}
\hline Quadrat & Vegetation form & sd & pH & OM & $\mathbf{P}$ & Al & $\mathbf{K}$ \\
\hline 1 & hyperseasonal cerrado & 5 & 4.3 & 47 & 3 & 6 & 2.4 \\
\hline 2 & hyperseasonal cerrado & 6 & 4.2 & 73 & 5 & 7 & 2.2 \\
\hline 3 & hyperseasonal cerrado & 6 & 4.1 & 44 & 4 & 8 & 2.1 \\
\hline 4 & hyperseasonal cerrado & 9 & 4.1 & 43 & 6 & 8 & 2.1 \\
\hline 5 & hyperseasonal cerrado & 6 & 4.2 & 49 & 4 & 9 & 2.2 \\
\hline 6 & hyperseasonal cerrado & 3 & 4.3 & 49 & 4 & 8 & 2.4 \\
\hline 7 & hyperseasonal cerrado & 4 & 4.2 & 36 & 4 & 6 & 1.8 \\
\hline 8 & hyperseasonal cerrado & 9 & 4.0 & 42 & 3 & 4 & 1.8 \\
\hline 9 & hyperseasonal cerrado & 4 & 4.2 & 54 & 5 & 7 & 2.3 \\
\hline 10 & hyperseasonal cerrado & 7 & 4.2 & 44 & 4 & 9 & 1.8 \\
\hline 11 & seasonal cerrado & 14 & 4.1 & 53 & 3 & 10 & 1.9 \\
\hline 12 & seasonal cerrado & 16 & 4.0 & 45 & 5 & 11 & 1.9 \\
\hline 13 & seasonal cerrado & 12 & 4.1 & 43 & 3 & 10 & 2.3 \\
\hline 14 & seasonal cerrado & 17 & 3.9 & 48 & 3 & 11 & 2.2 \\
\hline 15 & seasonal cerrado & 13 & 4.1 & 59 & 6 & 10 & 2.6 \\
\hline 16 & seasonal cerrado & 11 & 4.1 & 55 & 4 & 12 & 2.2 \\
\hline 17 & seasonal cerrado & 9 & 4.1 & 47 & 4 & 9 & 2.5 \\
\hline 18 & seasonal cerrado & 14 & 4.1 & 49 & 4 & 10 & 1.9 \\
\hline 19 & seasonal cerrado & 13 & 3.9 & 54 & 4 & 12 & 2.4 \\
\hline 20 & seasonal cerrado & 19 & 4.1 & 53 & 4 & 9 & 2.2 \\
\hline 21 & wet grassland & 15 & 4.1 & 125 & 12 & 18 & 2.3 \\
\hline 22 & wet grassland & 12 & 3.9 & 156 & 20 & 27 & 4.3 \\
\hline 23 & wet grassland & 24 & 3.9 & 155 & 31 & 32 & 4.0 \\
\hline 24 & wet grassland & 20 & 4.0 & 167 & 23 & 38 & 3.8 \\
\hline 25 & wet grassland & 16 & 4.0 & 193 & 24 & 30 & 3.2 \\
\hline 26 & wet grassland & 14 & 3.8 & 201 & 29 & 32 & 3.6 \\
\hline 27 & wet grassland & 20 & 3.8 & 167 & 21 & 24 & 4.5 \\
\hline 28 & wet grassland & 15 & 3.9 & 177 & 31 & 23 & 4.8 \\
\hline 29 & wet grassland & 16 & 3.9 & 173 & 27 & 30 & 4.2 \\
\hline 30 & wet grassland & 19 & 3.9 & 190 & 23 & 33 & 4.0 \\
\hline
\end{tabular}

species density, since this high concentration of aluminum can be toxic to the plants and decrease the species density.

Although phosphorus may influence grassland biodiversity (Janssens et al., 1998; McCrea et al., 2001) in temperate regions, it was not significantly related to species density in ENP's grasslands. Since the influence of phosphorus could be indirect by its control on the soil available nitrogen quantities (Janssens et al., 1998), it is possible that others factors were influencing the available nitrogen quantities in ENP. Low quantities of organic matter, for instance, reduce phosphorus limiting effect (Janssens et al., 1998) and may explain our results. Whereas high potassium levels diminished species diversity on former arable land (Gilbert and Andersen, 1998), potassium additions did not alter the floristic composition of hay plots (Elberse et al., 1983), what was corroborated by our results. The influence of organic matter on species density, on its turn, could be indirect by its control of the soil available nitrogen, primarily determined by the mineralization of organic nitrogen in the soil, which depends on the amount of soil organic matter (Roem and Berendse, 2000). Nitrogen is one of the main limiting factors of grassland richness (Janssens et al, 1998) and may be a good predictor of species density in tropical grasslands.

Vegetation and soils are dynamic systems, and relationships between particular vegetation characteristics and soil factors at one time may not always reflect the suitability of plant species present to that set of soil conditions (Critchley et al., 2002b). Our study is limited in time and there may be variations in soil characteristics and number of species in the three environments throughout the year due to the seasonal variations, such 
Table 2. Standardized partial regression coefficient $(\beta)$ and partial $\mathrm{F}$ values $(\mathrm{t})$ for multiple regressions between either species density or diversity and soil chemical factors, at $0-0.05 \mathrm{~m}$ deep, in grassland communities in Emas National Park, central Brazil $\left(18^{\circ} 15^{\prime}-18^{\circ} 18^{\prime} \mathrm{S}\right.$ and $\left.52^{\circ} 57-53^{\circ} 01^{\prime} \mathrm{W}\right)$, February 2003; organic matter (OM), phosphorus $(\mathrm{P})$, aluminum $(\mathrm{Al})$, potassium $(\mathrm{K})$, calcium (Ca) ; ${ }^{\mathrm{NS}} \mathrm{P}>0.05 ; * \mathrm{P}<0.05$; and $* * \mathrm{P}<0.01$.

\begin{tabular}{lcc}
\hline \multirow{2}{*}{ Factor } & \multicolumn{2}{c}{ Species density } \\
\cline { 2 - 3 } & $\beta$ & $\mathbf{t}$ \\
\hline $\mathrm{pH}$ & -0.57 & $-3.38^{* *}$ \\
$\mathrm{OM}$ & -0.57 & $-1.14^{\mathrm{NS}}$ \\
$\mathrm{P}$ & -0.00 & $-0.01^{\mathrm{NS}}$ \\
$\mathrm{Al}$ & 0.96 & $2.55^{*}$ \\
$\mathrm{~K}$ & -0.25 & $-0.51^{\mathrm{NS}}$ \\
\hline
\end{tabular}

as the temporary waterlogging in the hyperseasonal cerrado that would result in changes of chemical soil features (Gopal and Masing, 1990). These changes may imply differences in species density during the waterlogging when compared to the other seasons of the year. Nevertheless, even taking into account these limitations, species density in ENP's grasslands may be predicted by two soil factors: $\mathrm{pH}$ and aluminum. Since the predictable variation in species density is important to determining areas of conservation (Pärtel, 2002), we may postulate that these two soil factors are indicators of high species density areas in tropical grasslands, which could be used for assigning priority sites for conservation.

Acknowledgements - We are grateful to Fapesp for financial support and for the scholarships awarded; to Ibama, for research permission; to the Emas National Park staff, for logical assistance; and to CA. Casali, MV. Cianciaruso, RA. Miotto, IA. Silva, for their friendship and help in the field.

\section{References}

AL-MUFTI, MM., SYDES, CL., FURNESS, SB., GRIME, JP. and BAND, SR., 1977. A quantitative analysis of shoot phenology and dominance in herbaceous vegetation. J. Ecol., vol. 65 , p. 759-791.

AMORIM, PK. and BATALHA, MA., 2006. Soil characteristic of a hyperseasonal cerrado compared to a seasonal cerrado and a floodplain grassland: implications for plant community structure. Braz. J. Biol = Rev. Bras. Biol., vol. 66, no. 2B, p. 661-670.

ASKEW, GP. and MONTGOMERY, RF., 1983. Soils of tropical savannas. In GOODALL, DW. (ed.). Ecosystems of the worldtropical savannas. Berlin: Elsevier.

BATALHA, MA., SILVA, IA., CIANCIARUSO, MV. and DELITTI, WBC., 2005. Hyperseasonal cerrado, a new Brazilian vegetation form. Braz. J. Biol. = Rev. Bras. Biol., vol. 65, no. 4, p. 735-738.

BATALHA, MA. and MARTINS, FR., 2002. The vascular flora of the cerrado in Emas National Park (Goiás, Central Brazil). Sida, vol. 20, no. 1, p. 295-311.
BATALHA, MA. and MANTOVANI, W., 1999. Chaves de identificação das espécies vegetais vasculares baseada em caracteres vegetativos para a ARIE Cerrado Pé-de-Gigante (Santa Rita do Passa Quatro, SP). Revista Instituto Florestal, vol. 11, p. 137-158.

BOURLIÈRE, F. and HADLEY, M., 1983. Present-day savannas: an overview. In GOODALL, DW. (ed.). Ecosystems of the world - tropical savannas. Amsterdam: Elsevier.

BRAAKHEKKE, WG., 1980. On coexistence: a causal approach to diversity and stability in grassland vegetation. Agricultural Research Reports. Wageningen, The Netherlands.

CALBA, H. and JAILLARD, B., 1997. Effect of aluminium on ion uptake and H+ release by maize. New Phytol., vol. 137, p. 607-616.

CONSERVATION INTERNATIONAL, 1999. Ações prioritárias para a conservação do Cerrado e do Pantanal. Brasília Conservation International.

COUTINHO, LM., 1990. Fire in the ecology of the Brazilian cerrado. In GOLDAMMER, JG. (ed.). Fire in the tropical biota. Berlin: Springer.

CRITCHLEY, CNR., CHAMBERS, BJ., FOWBERT, JA., SANDERSON, RA., BHOGAL, A. and ROSE, SC., 2002a. Association between lowland grassland plant communities and soil properties. Biol. Conserv., vol. 105, p. 199-215.

CRITCHLEY, CNR., CHAMBERS, BJ., FOWBERT, JA., BHOGAL, A., ROSE, SC., and SANDERSON, RA., 2002b. Plant species richness, functional type and soil properties of grasslands and allied vegetation in English Environmentally Sensitive Areas. Grass Forage Sci., vol. 57, p. 82-92.

ELBERSE, WT., VAN-DER-BERGH, JP. and DIRVEN, JGP., 1983. Effects of use and mineral supply on the botanical composition and yield of old grassland on heavy-clay soil. Neth. J. Agr. Sci., vol. 31, p. 62-88.

FURLEY, PA., 1976. Soil-slope-plant relationships in the northern Maya mountains, Belize, central America. J. Biogeogr. vol. 3, p. 303-319.

GILBERT, OL. and ANDERSEN, P., 1998. Habitat Creation and Repair. Oxford: Oxford University Press.

GOPAL, B. and MASING, V., 1990. Biology and Ecology. In BC. PATTEN (ed.). Wetlands and shallow continental water bodies. SPB Academic Publishing, The Hague.

GRIME, JP., 1979. Plant Strategies and Vegetation Processes. Chichester, UK: John Wiley and Sons.

GRIME, JP., THOMPSON, K., HUNT, R., HODGSON, JG., CORNELISSEN, JHC., RORISON, IH., HENDRY, GAF., ASHENDEN, TW., ASKEW, AP., BAND, SR., BOOTH, RE., BOSSARD, CC., CAMPBELL, BD., COOPER, JEL., DAVISON, AW., GUPTA, PL., HALL, W., HAND, DW., HANNAH, MA., HILLIER, SH., HODKINSON, DJ., JALILI, A., LIU, Z., MACKEY, JML., MATTHEWS, N., MOWFORTH, MA., NEAL, AM., READER, RJ., REILING, K., ROSSFRASER, W., SPENCER, RE., SUTTON, F., TASKER, DE., THORPE, PC. and WHITEHOUSE, J., 1997. Integrated screening validates primary axes of specialization in plants. Oikos, vol. 79, p. 259-281.

JANSSENS, F., PETERS, A., TALLOWIN, JRB., BAKKER, JP., BEKKER, RM., FILLAT, F. and OOMES, MJM., 1998. Relationship between soil chemical factors and grassland diversity. Plant Soil, vol. 202, p. 69-78. 
JONGMAN, RHG., TER BRAAK, CJF. and VAN-TONGEREN, OFR., 1995. Data analysis in community and landscape ecology. Cambridge: Cambridge University. 299 p.

KÖPPEN, W., 1931. Grundriss der Klimakunde. Berlin: Gruyter.

MALAVOLTA, E., SARRUGE, JR. and BITTENCOURT, VC., 1977. Toxidez de alumínio e manganês. In FERRI, MG. (ed.). In V Simpósio sobre o cerrado. Itatiaia, Belo Horizonte.

McCREA, AR., TRUEMAN, IC., FULLEN, MA., ATKINSON, MD. and BESENYEI, L., 2001. Relationships between soil characteristics and species richness in two botanically heterogeneous created meadows in the urban English West Midlands. Biol. Conserv., vol. 97, p. 171-180.

MARRS, RH., 1993. Soil fertility and nature conservation in Europe: theoretical considerations and practical management solutions. Adv. Ecol. Res., vol. 24, p. 241-300.

MARSCHNER, H., 1989. Effect of soil acidification on root growth, nutrient and water uptake. In ULRICH, B. (ed.). Internat. Congr. Fores Decline Res. State of Knowledge and Perspectives. Universität Hohenheim, Stuttgart.

MOORE, DRJ. and KEDDY, PA., 1989. Relationship between species richness and standing crop in wetlands: the importance of scale. Vegetatio, vol. 79, p. 99-106.

MORGAN, JW., 1998. Patterns of invasion of an urban remnant of a species-rich grassland in southeastern Australia by nonnative plant species. J. Veg. Sci., vol. 9, p. 181-190.

PÄRTEL, M., 2002. Local plant diversity patterns and evolutionary history at the regional scale. Ecology, vol. 83, p. 2361-2366.

PIANKA, ER., 1994. Evolutionary ecology. New York: Harper Collins.
RAIJ, B., QUAGGIO, JA., CANTARELLA, H., FERREIRA, ME., LOPES, AS. and BATAGLIA, OC., 1987. Análise química de solos para fins de fertilidade. Campinas: Fundação Cargill.

RATTER, JA., RIBEIRO, JF. and BRIDGEWATER, S., 1997. The Brazilian cerrado vegetation and threats to its biodiversity. Ann. Bot., vol. 80, p. 223-230.

ROEM, WJ. and BERENDSE, F., 2000. Soil acidity and nutrient supply ratio as possible factors determining changes in plant species diversity in grassland and heathland communities. Biol. Conserv., vol. 92, p. 151-161.

RUGGIERO, PGC., BATALHA, MA., PIVELLO, VR. and MEIRELLES, ST., 2002. Soil-vegetation relationships in cerrado (Brazilian savanna) and semideciduous forest, Southeasthern Brazil. Plant Ecol., vol. 160, p. 1-16.

SARMIENTO, G., 1983. The savannas of tropical America. In GOODALL, DW. (ed.). Ecosystems of the world - tropical savannas. Berlin: Elsevier.

TILMAN, D., 1982. Resource competition and community structure. Princeton, New Jersey, USA: Princeton University Press.

UNESCO, United Nations Educational, Scientific, and Cultural Organization, 2001, Cerrado protected areas: Chapada dos Veadeiros and Emas National Parks. Paris. Available from: http:// www.unesco.org/whc/sites/1035.htm. Acessed: 10/02/2006.

VENTERINK, HO., WASSEN, MJ., VERKROOST, AWM. and RUITER, PC., 2003. Species richness-productivity patterns differ between N-, P- and K- limited wetlands. Ecology, vol. 84, p. 2191-2199.

VERMEER, JG. and BERENDSE, F., 1983. The relationship between nutrient availability, shoot biomass and species richness in grassland and wetland communities. Vegetatio, vol. 53, p. 121-126. 